\title{
Social Change and Community College Faculty: Is Effective Teaching Becoming Obsolete?
}

\author{
RICHARD L. ALFRED
}

Effective teaching is a product of faculty motivation and involvement in institutions which systematically recognize and reward quality instruction. For teaching to be effective, incentives for faculty involvement must be put forward by administrators over an extended period of time. Yet, the organization of faculty and curricula in community colleges provides limited incentives for "becoming involved." Faculty have become "tenants" within our institutions to the extent that: (1) they do not participate fully in strategic decisions about programs, finances and students; (2) they maintain limited interaction with students outside of the classroom due to the community-based role-set of commuting and part-time students; and (3) they engage in entrepreneurial interests outside of thecollege which limit the time and energy they can devote to instructional innovation and governance. "Burnout," "stress," and "alienation" are oft-repeated terms used to describe faculty. For an increasing number of community college faculty, primary satisfaction is no longer obtained through teaching, but through activities which lie outside of the classroom.

This essay will advance the argument that effective teaching is a highly valued but progressively obsolete function because of declining faculty involvement in teaching and learning associated with the sociological condition of "alienation." Alienation is a phenomenon peculiar to individuals exposed to conditions of rapid change in the external environment. As social conditions change, patterns of teaching behavior that were formerly successful in producing specific student learning outcomes are no longer successful. Expanded faculty interest and involvement in teaching is necessary to produce learning outcomes that are responsive to conditions of social change. 


\section{Dimensions of Effective Teaching}

Teaching effectiveness in the community college can be defined in terms of consequence between three dimensions: social change conditions, faculty expectations, and characteristics of the academic organization. It involves the expectation or probability held by faculty that the efforts they direct to teaching can determine the occurrence of specific student learning outcomes. When student outcomes fall short of faculty expectations, when effective performance is not recognized through formal and informal rewards, and when achievement of instructional objectives is hampered by marginal resources and changing social conditions, opportunities for enhancement of teaching will be limited.

\section{Teaching and Social Change}

Viewing teaching effectiveness as a three-dimensional construct, how do conditions of social change in the external environment-economic, technological, demographic, labor market, and public policy-encourage or impede teaching effectiveness? Following are four social change conditions that will impact the teaching effectiveness of community college faculty in the $90 \mathrm{~s}$ :

- Changing Economic Conditions: Pressing issues remain to be addressed by public officials that could adversely impact community college budgets through disruption of the flow of federal revenues to the states. Included among these issues are the federal budget deficit, the import/export imbalance, tax reform, weakened international competitive position, economic recovery based on total consumption in contrast to corporate investment, and increasing domestic spending requirements. Human service organizations will respond to federal cutbacks through deinstitutionalization strategieslowering fixed costs for operations through reduction of the number of clients served. At issue will be the ability of community colleges to document impacts that can compete favorablywith those documented by human service organizations in states experiencing resource decline.

Impact: Community colleges will not be able to provide the full complement of resources forinstruction (equipment, supplies, and faculty development) required to produce desired learning outcomes in students. Teaching effectiveness will decline in the face of a three-pronged dilemma: (1) absolute reduction in resources available for the acquisition of instructional equipment and supplies due to growing incapacity of the college to compete effectively with human service organizations for limited state resources, (2) growing problems with "fixed costs" for maintenance-energy, faculty salaries, facilities maintenance, and computing-which will consume discretionary income that could be applied to program and faculty development, and (3) growing requirements for resource reallocation based on a process of program review with negative impacts on faculty morale as academic programs are modified or eliminated.

- Demographic Transition. The age distribution and family structure in American society is undergoing rapid change. By 1995, an increasing percentage of citizens will be represented in the 55 and older age group compared to their representation. Concurrent with this trend will be the emergency of the single parent family as a prominent force in society. Between 1970 and 1980, 
the number of children $0-18$ years of age raised in single-parent families increased from 8.8 million to 12.2 million. In the decade 1980-1990, approximately $50 \%$ of the children in the $0-18$ age group will be raised in the single-parent family at some point in this age interval. While seemingly innocuous as a statistic to community colleges, demographic data of this type have powerful implications for student choice and federal financial aid policy. Children "rushed through" adolescence by adults seeking to replace a missing partner may attempt to make up for lost years of adolescence through college selection. The residential four-year college affords extensive opportunities for peer interaction. If marketed carefully for appeal to recent high school graduates reared in single-parent families, four-year colleges could increase their market share of high school graduates directly at the expense of community colleges.

Impact: The community-based role-set of community college students will become a powerful force in educational and career goal selection. Frustration will rise among faculty as control over student values in the teaching/learning process diminishes in a welter of competing interests for student time and attention. Faculty may experience diminished feelings of self-worth as their "impact" on what students want to learn and actually do learn begins to erode in the face of changing needs associated with change in the family structure.

- Changing Structure of the Labor Market. The rapid application of technology to the labor market has led to the restructuring of manufacturing, service and technology industries. Growth is expected in service occupations where a large proportion of the jobs will be located,high-technology occupations in which a small proportion of jobs will be located, and low-technology occupations. In a labor market marked by changing educational requirements associated with change in technology and the structure of jobs, important questions loom as to the value of the associate degree. Does the degree constitute over-education for service occupations with the advantage offset to proprietary institutions offering non-accredited, short-term courses? Does the degree constitute undereducation for technological occupations with the advantage gained by universities offering technological courses at the baccalaureate degree level? What is the value of the associate degree in a changing labor market?

Impact: More and more, community colleges will focus on a public service mission of short-term job training and retraining with a non-degree emphasis. Business and industry specifications for faculty teaching skills, equipment, and course content will change rapidly as technology and market conditions dictate. Degree programs will shift in primacy as will the value of the associate degree. Traditional work expectations held by community college faculty regarding employment, salary and benefits, and autonomy in curriculum and course decisions will no longer be guaranteed. Faculty will experience increasing anxiety as market factors begin to intervene with traditional values they hold about academic freedom, job security, and control over the curriculum.

- Future Change in Government Spending Priorities. Recent studies have shown that the percentage of the United States population living at or below 
the poverty level to be 15.2 percent-the worst since 1964 . Poverty will become a significant public policy issue in the late $80 \mathrm{~s}$. It will become a focus for resource allocation as government agencies target money for special purpose programs to meet the needs of disenfranchised groups which, if neglected, could lead to social unrest. "Access" will once again become an important policy issue for two-year colleges to address the changing learning requirements of a population increasingly divided into "haves" and "have nots" by income, occupational status, and economic mobility. Frustration experienced by disaffected groups holding low-income jobs in a technological economy will result in new or expanded programs for job development, job retraining and adaptation to technology. Federal and state agencies will employ financial incentives to encourage community colleges to relax admissions and retention standards in associate degree programs. Education for low-income and displaced workers will become increasingly important as a method to provide opportunity for expansion of personal income through training in technology.

Impact: Community colleges lacking slack in their organizational structure will experience difficulty in acquiring significant new resources from government agencies in the late 80s unless administrators are attuned to public policy issues in a postindustrial economy. Faculty who have become accustomed to a continuing emphasis on quality and standards for student performance and progression will experience counter pressures for "retention" and "absorption" from administrators and external groups. The threat of social unrest in a technological economy will cast a new light on the role of community college faculty - that of "adaptation" of disenfranchised population subgroups to changing economic and technological conditions. Since the faculty in a computer institution are the major source of contact with students, only they can perform this role. At issue will be the structure of the academic reward system and whether or not it will support an "adaptive" role for faculty. Will the academic reward system change to recognize dimensions of adaptation such as effective advising, student retention, and student satisfaction as criteria for promotion and merit award decisions?

These conditions can culminate in organizational malaise for community college faculty and administrators if careful efforts are made toward institutional renewal. A "resource rich" institution has unlimited freedom to make decisions about academic programs and an open growth curve with untapped clienteles. It functions differently than an institution that has the opposite growth profile. The question to be asked by administrators is: What is the impact of organizational malaise on teaching and learning and what adverse public perceptions might emerge as external agencies and officials move to improve lagging productivity of community college faculty? The community college that seeks to shape the course of public opinion in the future must function as a productive institution capable of eliciting the support and enthusiasm of its faculty for improvement of teaching and learning.

\section{Teaching and Characteristics of the Academic Organization}

The negative effects of changing social conditions on teaching effectiveness can 
be mitigated by an academic organization that successfully adapts programs and faculty to social change. A prominent characteristic of the academic organization in community colleges today is the condition of "alienation"-a value or attitude among faculty that results in estrangement from the teaching/learning process. There are five dimensions of alienation documented in the sociological literature that have an application to community college faculty detailed below:

- Meaninglessness. A dimension of alienation conceived as the expectancy or probability held by faculty that their behavior cannot determine the occurrence of specific learning outcomes or reinforcements that they seek with students. When administrators hold the prerogative and the means of making decisions about enrollment levels, staffing, and equipment and supply budgets, faculty are rendered ineffective in controlling the resources necessary to produce desired student learning outcomes. Community college faculty do not participate directly in resource allocation decisions nor do they control planning and evaluation processes. This condition of powerlessness is sustained through insufficient research evidence about long- and shortterm student outcomes in academic programs. When information documenting the outcomes of teaching is absent over an extended period of time, faculty satisfaction and commitment cannot be nurtured through the reward of positive feedback.

- Normlessness. A dimension of alienation that refers to the expectancy among faculty that institutionally unapproved behavior is required to achieve individual and group goals. Normlessness develops among community college faculty when commonly-held values-academic freedom, collegiality, job security, etc.-are submerged in a welter of competing interests of administrators and trustees seeking satisfaction by any means that are available (retrenchment, reallocation, and reduction). An important function of community college management is to provide a basis for predictability and regularity of resource conditions and allocation practices. In the absence of such predictability, faculty attention is focused on "maintenance" concerns implicit in collective bargaining rather than "developmental" concerns implicit in teaching and learning.

- Isolation. The process of detachment experienced by community college faculty who assign a low-reward value to goals and believes that are highly valued by administrators, trustees, other faculty, and external groups. When administrators emphasize the need for enrollment maintenance in student development in contrast to faculty emphasis on quality control and academic standards, when faculty resist the comprehensive community college mission and administrators embrace this mission, and when faculty increase their involvement in off-campus entrepreneurial activities and view the institution as a secondary source of satisfaction in contrast to administrator perceptions of the institution as a primary source of satisfaction, isolation may be said to be characteristic of community college faculty.

- Self-estrangement. A dimension of alienation that concerns the degree of faculty dependence upon anticipated future rewards controlled by administrators that alter the outcomes and benefits of teaching. The instructor who works merely for salary and job security and who assigns passing grades to students only for their effect on retention and degree production rates will experience self-estrangement. Self-estrangement refers to the inability of 
faculty to experience teaching as a self-rewarding activity that engages them. Teaching is not valued in itself, nor is learning -it is only valued for its effect on those who control the reward system.

\section{Strategies for Enhancement of Teaching Effectiveness}

Clearly faculty commitment to teaching and learning is impacted by changing conditions in the external environment and the structure of the academic organization-factors which encourage alienation because faculty cannot shape and determine the allocation of resources to instruction. What can be done to address the problem of diminished teaching effectiveness among community college faculty? One approach would be to attack the dimensions of alienation with an action program designed to counteract the negative effects of estrangement. The focus of this program would be institutional processes and activities which improve faculty control over resources applied to the teaching/learning process and information about student learning outcomes. The "action program" can be organized in accord with the specific dimensions of alienation as follows:

- Powerlessness: (1) Provide faculty with improved entering student profile data (demographic, intellective and perceptual-attitudinal) and undertake an in-service faculty development program to familiarize them with the uses of student profile data as a method to identify desired learning outcomes in students; and (2) engage faculty in systematic and ongoing student-outcomes research (long- and short-term) as a method to demonstrate the relationship between student aptitudes, teaching strategies, and student learning outcomes. Focus the research effort on the principle of "value-addedness" produced in learners through exposure to different teaching and learning strategies.

- Meaninglessness: Increase faculty involvement in academic planning and budgeting at the academic department level to encourage the development of "stakeholder values" among individual instructors. Expanded involvement of faculty should be encouraged in the assessment of technological change, demographic transition, labor market trends, economic conditions and public policy.

- Normlessness: (1) Improve the faculty-reward system to ensure congruency between faculty expectations and the performance criteria against which reward decisions are made. Focus faculty and administrative attention on the development of consensual goals about the following dimensions of instructional performance: student abilities and learning outcomes, instructional productivity measured in student enrollment and course retention rates, faculty expectations and performance in activities outside of the classroom such as academic advising. (2) Establish "quality circles" comprised of faculty, administrators, lay advisory personnel, and trustees (where appropriate) to examine key curriculum and professional development issues facing faculty and to propose alternative solutions based on different blends of public- and private-sector resources.

- Isolation: (1) Increase the level of faculty involvement in formally and informally organized institutional activities designed to formulate academic policies and procedures regulating student enrollment, student mix, student flow, and learning outcomes. Focus on consensus building among groups 
with differential values related to the following dimensions of student flow: student mix and entry-level competencies, student academic performance and progression standards, student retention and graduation rates, and student academic competencies at graduation. (2) Maximize faculty opportunities for training and retraining in public- and private-sector organizations as a method to forge goal consensus among (a) faculty who impart knowledge to students and (b) "external organizations" which "receive" the benefits of knowledge production with students. Strive for consensus between faculty and "receiving organizations" in the following areas of academic performance: knowledge and technical skills required for students, course content, instructional strategies, equipment inventory, student number and mix, instructor skills and experience, academic support services, marketing strategies, and liberal arts/general education requirements for students.

- Selfestrangement: Perform a "values audit" using small groups of faculty, administrators, trustees and external agency personnel to identify common and differentiated values related to teaching and learning that can be reinforced in the faculty-reward system. Faculty need to obtain primary satisfaction through teaching and learning. Rewards should be granted only when faculty show evidence of instructional behavior which leads to desired student learning outcomes specified in the faculty-reward system.

\section{Conclusion}

Essentially, what has been proposed in this essay is that it is not solely the act of teaching in and of itself that engenders effective teaching. It is the conditions inside and outside the environment in which teaching and learning take place that coalesce to facilitate or impede effective teaching. Academic leaders may lack the confidence and insight to assert that effective teaching should stand for something more than faculty skills in the classroom. Too many community colleges have no clear sense of the values, expectations, and resources they should apply in teaching and learning. Faculty and administrators need to work together to reconstruct the teaching environment to reward teaching effectiveness based on the premise that faculty can determine the occurrence of specific learning outcomes in students, through expanded participation in decisions regulating the flow of resources to academic programs.

\section{Note}

This essay was developed and presented to the Convention of the American Association of Community and Junior Colleges, April, 1985, San Diego, California.

Richard L. Alfred is Associate Professor and Program Chair, Higher and Adult Continuing Education, University of Michigan, Ann Arbor, Michigan. 